International Journal on Social Science, Economics and Art, 11 (4) (2022) 165-171

\title{
The Effect of Financial Statement Integration and Accountability Characteristics on Taxpayer Compliance Moderated by Nationalism
}

\author{
Sihar Tambun ${ }^{1}$, Pita Rizki Handayani ${ }^{2}$ \\ ${ }^{1,2}$ Faculty of Economy and Business, Universitas 17 Agustus 1945 Jakarta
}

\begin{tabular}{|c|c|}
\hline Article Info & ABSTRACT \\
\hline Article history: & \multirow{10}{*}{$\begin{array}{l}\text { The purpose of the study to prove nationalism as a moderating variable } \\
\text { among the influence on the integration of financial statements and } \\
\text { characteristics can be accounted for to taxpayer compliance. This type } \\
\text { of research uses quantitative research methods. Quantitative research is } \\
\text { research with data analyzed in the form of numbers. Quantitative } \\
\text { descriptive research methods with the use of numbers from data } \\
\text { collection, interpretation of data and exposure of results. This research } \\
\text { procedure is done by conducting a questionnaire. Questionnaires are } \\
\text { distributed using google form. The results of the study found that 1) } \\
\text { financial statements intregation, characteristics can be accounted, and } \\
\text { nationalism attitudes have a positive and significant effect on taxpaye } \\
\text { compliance and 2) moderation of national attitudes on the integration } \\
\text { of financial statements has no positive effect on taxpayer compliance } \\
\text { while the moderation of national attitudes on characteristics can be } \\
\text { accounted for positively on taxpayer compliance. }\end{array}$} \\
\hline Received: Jan 26, 2022 & \\
\hline Revised: Feb 07, 2022 & \\
\hline Accepted: Feb 12, 2022 & \\
\hline Keywords: & \\
\hline & \\
\hline Statements: & \\
\hline Nationalism Attitudes; & \\
\hline Taxpayer Compliance. & \\
\hline & \\
\hline
\end{tabular}

This is an open access article under the CC BY-NC license.

\section{Corresponding Author:}

Pita Rizki Handayani

Faculty of Economy and Business

Universitas 17 Agustus 1945 Jakarta,

Jl. Sunter Permai Raya No.1, DKI Jakarta 14350, Indonesia

Email: pitarizkihandayani@gmail.com

\section{INTRDUCTION}

The Covid-19 pandemic has hit almost the entire country and has had an impact in various fields, various countries are trying to prevent the spread of the virus by implementing a lock down system. The implementation of the lock down system has an impact on trade and industrial traffic which is not allowed to carry out activities temporarily (Brodeur et al., 2021). The Covid-19 pandemic has also had an impact on the Indonesian economy. Indonesia's State Revenue and Expenditure Budget (APBN) in the last five years has been volatile and experienced an increase in deficit in 2020. In 2016 the Indonesian State Budget was Rp. 1,285 trillion, increased in 2017 and 2018 by Rp. 1,344 trillion and Rp. 1,519, again decreased in 2019 by Rp1,546 and decreased in 2020 by Rp1,405 trillion. During 2020, the government has twice changed the APBN as a step to restore the national economy due to declining tax revenues. The decline in tax revenue due to the weakening in the business sector. In 2020, tax revenue only reached Rp13.65 trillion or $44.02 \%$ compared to 2019 which reached Rp604.3 trillion or decreased by $12.01 \%$. The taxes paid by the community are used for the benefit of realizing the welfare and quality of life together. Increasing state tax revenues can help strengthen the country's economy (Obando \& Aguilar, 2020). Taxpayers, both business entities and individuals, have an important role in increasing taxes and are 
urgently needed in an effort to support taxpayer compliance. In addition, transparency of financial statements, integration of financial statements, and an attitude of nationalism in moderating management accountants is required so that it can affect taxpayer compliance and increase taxpayer income.

Research on the integration of financial statements, the characteristics of accountability, and the attitude of nationalism towards taxpayer compliance has been widely carried out. Research conducted by Darono (2020); Mudiaga Daniel \& Olusola Esther, (2019); Sayidah \& Assagaf, (2019); Whait et al., (2018) dan Maulana \& Marismiati (2020) related to the integration of financial statements on taxpayer compliance. Research conducted by Kiha \& Nenomnanu (2020); Sista (2019); Alhempi et al., (2020); Bachas et al., (2019); dan Purba et al., (2020) related to the characteristics of being accountable for taxpayer compliance. Chetisa Putri \& Venusita (2019); Tambun \& Haryati (2022); Hanifah \& Yudianto, (2019); Mayapada et al., (2021); dan Idrus et al., (2020) linking the attitude of nationalism to taxpayer compliance.

The difference between this research and previous research lies in the choice of nationalism as a moderating variable for the integration of financial statements and the characteristics of being accountable for taxpayer compliance. This study places the attitude of nationalism as a moderating variable between the effect on the integration of financial statements and the characteristics of being accountable for taxpayer compliance moreover the novelty of the research lies in choosing the attitude of nationalism as a moderating variable. The focus of the research is to prove the attitude of nationalism as a moderating variable between the effect on the integration of financial statements and the characteristics of being accountable for taxpayer compliance.

\section{RESEARCH METHOD}

This type of research uses quantitative research methods. Quantitative research is research with data analyzed in the form of numbers. Descriptive quantitative research method using numbers from data collection, interpretation of data and presentation of results. Research variables consist of independent, dependent, and moderating variables. The independent variable is the integration of financial statements and the characteristics of being accountable. The dependent variable is taxpayer compliance. The moderating variable is the attitude of nationalism.

The procedure of this research is done by distributing questionnaires. Questionnaires were distributed using google forms. After being distributed, the data was collected and analyzed and then presented as a research report. The questionnaire research instrument was selected and arranged based on the indicators and sub-indicators of the variables. The results of the data that have been collected are then analyzed with the following steps: 1) Data collection questionnaire, 2) Data validity test, 3) Data reliability test, 4) Hypothesis test. This test is used to see the effect of each independent variable on the effect of the dependent variable. The tool used in the test is the Smart PLS program, the hypothesis is accepted if the significance value is between the results of p value 1.96, so the hypothesis can be accepted and significant, and 5) Coefficient of Determination. This test can provide an explanation of the effect of variations in related variables and can create multiple regression equations that have benefits in seeing changes in the influence of the dependent variable on the independent variable. This test can be known by looking at the $R$-Square.

\section{RESULTS AND DISCUSSION \\ 3.1 Result}

The results of research data that have been collected, processed, and then analyzed. Data analysis using SmartPLS 3.o. In conducting data analysis, the steps used are: 1) descriptive statistics, 2) validity tests, 3) reliability tests, 4) hypothesis testing, and 5) determination coefficient tests.

\section{a. Statistik Deskriptif}

Respondents used as many as 241 respondents, using simple random sampling with hair method at least $5 \mathrm{x}$ the number of indicators. The results of the data in this study, obtained from questionnaires 
distributed to respondents using google form. The following table 1 presents the results of descriptive statistical tests.

Tabel 1. Descriptive statistics

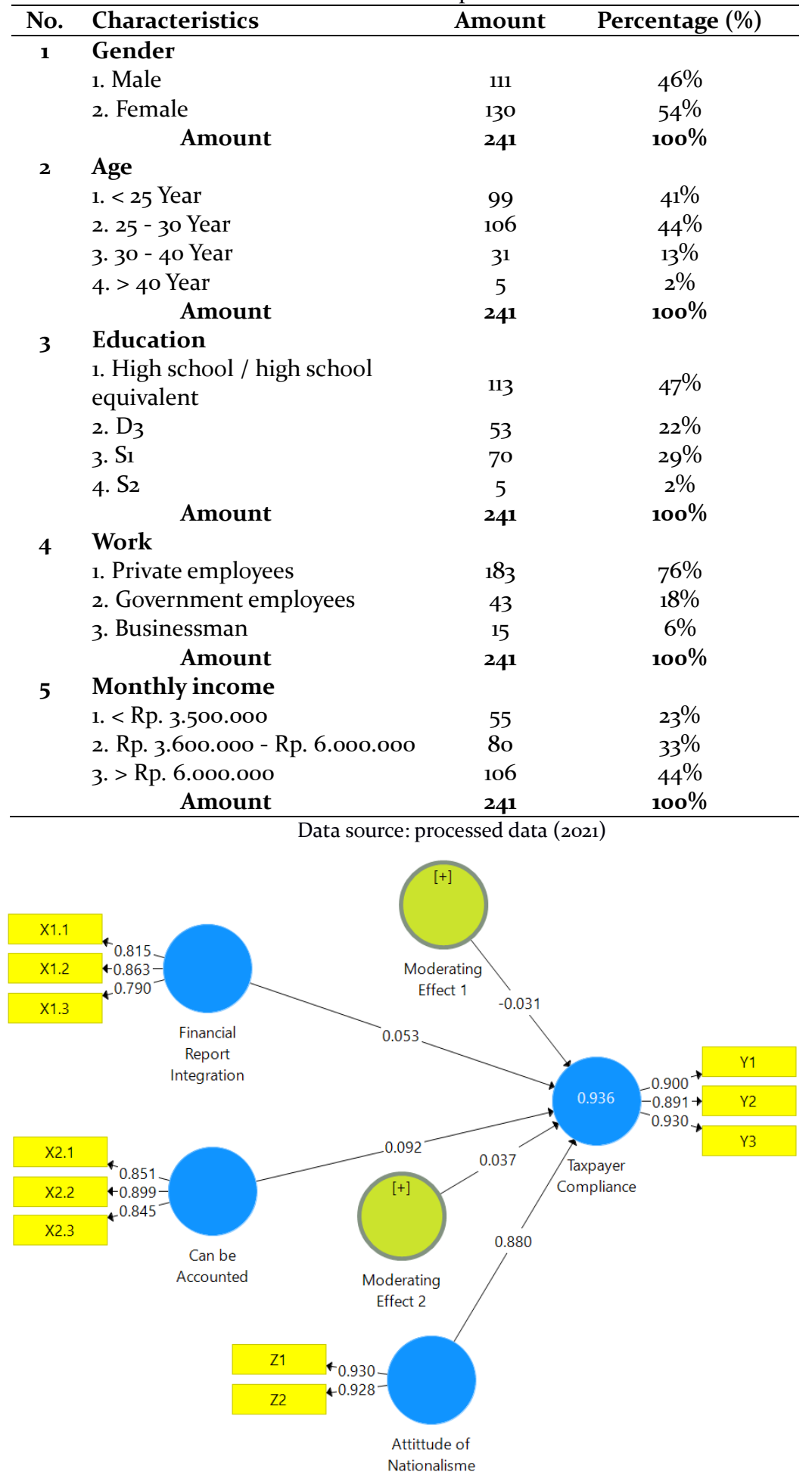

Figure 1. Analysis Results Using SmartPLS 


\section{b. Uji Validitas}

1) The results of the validity test on the taxpayer compliance variable with three indicators are declared valid. Overall indicator result $>0.5$.

2) The results of the validity test on the financial statement integration variable with three indicators are declared valid. Overall indicator result $>0.5$.

3) The results of the validity test on the characteristic variables can be accounted for with three indicators declared valid. Overall indicator result $>0.5$.

4) The results of the validity test on the nationalism attitude variable with two indicators were declared valid. Overall indicator result >0.5.

\section{c. Uji Reabilitas}

The reliability test is known by calculating the magnitude of the Cronboach Alpha score on several variables. The answers from 241 respondents were declared reliable if the score was $>0.7$. The following are the results of the reliability test.

Tabel 2. Uji Reabilitas

\begin{tabular}{lcc}
\hline Variabel & Cronboach Alpha & Ket \\
\hline Attitude of Nationalism $\left(\mathrm{X}_{1}\right)$ & 0,841 & Valid \\
Financial Report Integration $\left(\mathrm{X}_{2}\right)$ & 0,762 & Valid \\
Can be Accounted (Z) & 0,833 & Valid \\
Taxpayer Compliance & 0,892 & Valid \\
\hline
\end{tabular}

\section{d. Koefisien Determinasi}

Based on the tests that have been carried out, it is known that the $\mathrm{R} 2$ value is 0,936 . These results indicate that the variables of financial statement transparency, financial statement integration, and professional ethics of management accountants have an effect on taxpayer compliance by 0,936 or $93,6 \%$, the rest is influenced by other variables not examined.

\section{e. Uji hipotesis}

Tabel 3. Uji Hipotesis

\begin{tabular}{|c|c|c|c|c|c|}
\hline Variabel & $\begin{array}{c}\text { Original } \\
\text { Sample }\end{array}$ & Sample & $\begin{array}{l}\text { Stand. } \\
\text { deviasi }\end{array}$ & T-Statitistics & P Values \\
\hline $\mathrm{X}_{1}->\mathrm{Y}$ & 0,053 & 0,055 & 0,017 & 3,193 & 0,001 \\
\hline $\mathrm{X}_{2} \rightarrow \mathrm{Y}$ & 0,092 & 0,090 & 0,024 & 3,823 & 0,000 \\
\hline $\mathrm{Z}->\mathrm{Y}$ & 0,880 & 0,880 & 0,020 & 4,748 & 0,000 \\
\hline Moderasi Z -> X1 -> Y & $-0,031$ & $-0,032$ & 0,013 & 2,391 & 0,009 \\
\hline Moderasi Z -> X2 -> Y & 0,037 & 0,037 & 0,018 & 2,111 & 0,018 \\
\hline
\end{tabular}

Hypothesis testing is carried out to see the significance of each path coefficient that provides a statement based on the influence on the construct. A hypothesis can be accepted and significant if $\mathrm{P}$ Value $<0,5$ and T statistic $<1,96$. Following are the results of the hypothesis.

1. The first hypothesis has a P value of o,oo1 and a T statistic of 3,193. Thus the first hypothesis is declared accepted.

2. The second hypothesis has a P value of o,ooo and a T statistic of 3,823. Thus the second hypothesis is declared accepted.

3. The third hypothesis has a P value of o,ooo and a T statistic of 4,748 . Thus the third hypothesis is declared accepted.

4. The fourth hypothesis has a P value of o,oog and a T statistic of 2,391. Thus the fourth hypothesis is accepted.

5. The fifth hypothesis has a $\mathrm{P}$ value of 0,018 and a T statistic of 2,111. Thus the fifth hypothesis is declared accepted. 


\subsection{Discussion}

\section{a. Effect of Financial Statement Integration on Taxpayer Compliance}

The results of the study of hypothesis testing found that the first hypothesis had a P value of o,oor and a T statistic of 3,193. Thus the first hypothesis is declared accepted. That is, the higher the level of integration of financial statements, the positive and significant effect on taxpayer compliance. The integration of financial statements is expected to increase taxpayer compliance in paying their obligations (Abdullah et al., 2021). According to Utami (2018) that the conceptual design is realized in the integration of financial statements that apply technology as an alternative to tax payments that can help increase tax revenue. The results of this study are in line with Putra \& Setiawan (2020) shows that the integration of financial statements can have a positive effect on taxpayer compliance.

\section{b. The Effect of Accountability on Taxpayer Compliance}

The results of the second hypothesis test have a P value of o,ooo and a T statistic of 3,823. Thus the second hypothesis is declared accepted. That is, the better the level of accountability, it will increase taxpayer compliance as well. Accountability can be used as an indicator to assess a service that is categorized as quality (Fau et al., 2019). Research result by Kiha \& Nenomnanu (2020) states that being accountable affects public compliance in paying taxes. According to Sista (2019) that services that are accounted for and carried out continuously can satisfy the community and serve as a condition for meeting service standards.

\section{c. The Influence of Nationalism's Attitude on Taxpayer Compliance}

The results of the third hypothesis test have a P value of o,ooo and a T statistic of 4,748. Thus the third hypothesis is declared accepted. That is, there is a significant influence between the attitude of nationalism on taxpayer compliance. That is, taxpayers who have a high attitude of nationalism can increase taxpayer compliance. The attitude of nationalism as a manifestation of the attitude of the people in loving their own nation. The attitude of nationalism can also be used as an indicator that there is a good relationship between the state and society, so as to create harmony and peace. Chetisa Putri \& Venusita (2019) that the attitude of nationalism is very influential on taxpayer compliance.

d. The Effect of Financial Statement Integration on Taxpayer Compliance Moderated by Nationalism

The results of the fourth hypothesis test have a P value of o,oog and a T statistic of 2,391. Thus the fourth hypothesis is accepted. This means that there is a significant influence between the attitude of nationalism and the integration of financial statements on taxpayer compliance. The integration of financial statements is the provision of information stated in the financial statements and can be explained in detail, honestly, and real. The results of this study are the same as the results of research which conducted Etim et al., (2020) and Maulana dan Marismiati (2020) shows that the integration of financial reports makes the public more confident in the performance of the government. In addition, people who are proud of their country and feel obliged to pay taxes.

\section{e. The Effect of Accountability on Taxpayer Compliance Moderated by Nationalism}

The results of the fifth hypothesis test have a P value of 0,018 and a T statistic of 2,111. Thus the fifth hypothesis is declared accepted. That is, these results can prove that there is an accountable effect on taxpayer compliance which is moderated by the attitude of nationalism. People who have a high attitude of nationalism are more responsible for their obligations to pay taxes (Idrus et al., 2020). According to Macintyre et al., (2021) his research results that citizens who have a sense of pride in their country tend to prefer to be obedient in paying taxes.

\section{CONCLUSION}

Based on the test results, it can be concluded as follows. (a). There is a significant effect of financial statement integration on taxpayer compliance. The results of the study of hypothesis testing found that the first hypothesis had a P value of o,oor and a T statistic of 3,193. Thus the first hypothesis is declared accepted. That is, the higher the level of integration of financial statements, the positive and significant effect on taxpayer compliance. (b). There is a significant influence that can be accounted for on taxpayer compliance. The results of the second hypothesis test have $\mathrm{P}$ value of o,ooo and a T statistic of 3,823. 
Thus the second hypothesis is declared accepted. That is, the better the level of accountability, the better taxpayer compliance. (c). There is a significant influence of the attitude of nationalism on taxpayer compliance. The results of the third hypothesis test have a P value of o.ooo and a T statistic of 4.748. Thus the third hypothesis is declared accepted. That is, there is a significant influence between the attitude of nationalism on taxpayer compliance. (d). There is a significant effect of financial statement integration on taxpayer compliance moderated by nationalism. The results of the fourth hypothesis test have a P value of 0.009 and a T statistic of 2.391. Thus the fourth hypothesis is accepted. This means that there is a significant influence between the attitude of nationalism and the integration of financial statements on taxpayer compliance. (e). There is a significant influence of accountability characteristics on taxpayer compliance which is moderated by the attitude of nationalism. The results of the fifth hypothesis test have P value of 0.018 and T statistic of 2.111. Thus the fifth hypothesis is declared accepted. That is, these results can prove that there is an accountable effect on taxpayer compliance which is moderated by the attitude of nationalism.

\section{ACKNOWLEDGEMENTS}

There are no words that deserve to be said other than gratitude for the presence of Allah SWT with His abundance and grace, the researcher was able to complete the MBKM Research entitled "The effect of the integration of financial statements and accountability characteristics on taxpayer compliance moderated by the attitude of nationalism". The researcher realizes that in the process of writing this scientific paper, there are many obstacles but thank to Allah SWT and the help of various parties so that the obstacles faced can be overcome. On this happy occasion, the researcher does not forget to thank all those who have provided guidance, direction, advice and thoughts in writing this paper.

\section{REFERENCES}

Abdullah, R., Jabu, F. A., Salim, W., Ekonomi, F., Sultan, I., \& Gorontalo, A. (2021). PENTINGNYA PROFESI AKUNTAN DALAM PENGEMBANGAN LAPORAN KEUANGAN KEUANGAN DESA. Jurnal Valuasi: Jurnal Ilmih, Ilmu Manajemen Dan Kewirausahaan, 1(2), 545-566.

Alhempi, R. R., Ardiansyah, I., Kusumastuti, S. Y., \& Endri, E. (2020). Tax compliance in income tax payments. International Journal of Innovation, Creativity and Change, 13(1), 356-374.

Bachas, P., Fattal Jaef, R. N., \& Jensen, A. (2019). Size-dependent tax enforcement and compliance: Global evidence and aggregate implications. Journal of Development Economics, 140(March), $203-222$. https://doi.org/10.1016/j.jdeveco.2019.05.001

Brodeur, A., Gray, D., Islam, A., \& Bhuiyan, S. (2021). A literature review of the economics of COVID-19. Journal of Economic Surveys, 35(4), 1007-1044. https://doi.org/10.1111/joes.12423

Chetisa Putri, K., \& Venusita, L. (2019). The Effect of Gender, Education, and Nationalism Level of Individual Taxpayers Toward Tax Mojokerto Compliance: A Case Study on Kpp Pratama. KnE Social Sciences, 3(11), 170. https://doi.org/10.18502/kss.v3i11.4006

Darono, A. (2020). Integrasi Informasi Dan Cooperative Tax Compliance: Analisis Institusional Komparatif. Jurnal BPPK: Badan Pendidikan Dan Pelatihan Keuangan, 13(2), 87-99. https://doi.org/10.48108/jurnalbppk.v13i2.638

Etim, R. S., Jeremiah, M. S., \& B. S. Dan, P. (2020). Tax Compliance and Digitalization of Nigerian Economy: The Empirical Review. American International Journal of Social Science, 9(2), 42-50. https://doi.org/10.30845/aijss.v9n2p5

Fau, M., -, S., \& -, K. (2019). Determinan Kepatuhan Wajib Pajak Orang Pribadi dalam Pemenuhan Kewajiban Perpajakannya di Lembaga Pendidikan Yayasan Swasta Katolik. InFestasi, 14(2), 103. https://doi.org/10.21107/infestasi.v14i2.4855

Hanifah, H., \& Yudianto, I. (2019). The Influence of Religiosity, Nationalism, and Tax Corruption Perception on Tax Compliance: Study of The Micro, Small and Medium Enterprises (MSMEs) Taxpayers in Bandung City. Journal of Accounting Auditing and Business, 2(1), 17. https://doi.org/10.24198/jaab.v2i1.20428

Idrus, A., Lalo, A., Tenreng, M., \& Badruddin, S. (2020). Tax Compliance With Taxpayer Awareness As an Intervening Variable. Humanities \& Social Sciences Reviews, 8(1), 586-594. https://doi.org/10.18510/hssr.2020.8170

Kiha, E. K., \& Nenomnanu, F. (2020). Analisis Faktor-Faktor Yang Mempengaruhi Kepatuhan Wajib Pajak Bumi Dan Bangunan Di Kecamatan Kota Kefamenanu. Ekopem: Jurnal Ekonomi ..., 5(2), 27-37. 
Macintyre, A., Chan, H, F., \& Schaffner. (2021). National Pride and Tax Compliance: A Laboratory Experiment Using a Physiological Marker.

Maulana dan Marismiati. (2020). Pengaruh Penerapan Sistem E-Filing Terhadap Kepatuhan Wajib Pajak Orang Pribadi ( Studi Kasus Pada Pegawai di Lingkungan Politeknik Pos Indonesia ). Jurnal Revenue : Jurnal Ilmiah Ilmu Akuntansi, 1(2), 1-10.

Mayapada, A. G., Muliati, M., Tampang, T., \& ... (2021). The Determinants of Tax Compliance: Loving or Fearing. Jurnal Akuntansi Kontemporer, 13(2), 122-131.

Mudiaga Daniel, A., \& Olusola Esther, I. (2019). Electronic Taxation and Tax Compliance Among Some Selected Fast Food Restaurants in Lagos State, Nigeria (Tax Payers Perspective). European Journal of Accounting, Auditing and Finance Research, 7(7), 52-80.

Obando, R. R., \& Aguilar, J. A. (2020). Tax Insights from Latin American and Caribbean in the Context of COVID19. American Scientific Research Journal ..., 128-142.

Purba, H., Sarpingah, S., \& Nugroho, L. (2020). The Effect Of Implementing E-Filing Systems On Personal tax Compliance With Internet Knowledge As Moderated Variables (Case Study On Personal Taxpayers at KPP Pratama Jakarta Kramatjati). International Journal of Commerce and Finance, 6(1), 166-180.

Putra, I. N. A., \& Setiawan, P. E. (2020). The Effect of Taxpayer Awareness, Service Quality, Taxation Understanding , and Application of E-Filling System on Corporate Taxpayer Compliance. American Journal of Humanities and Social Sciences Research (AJHSSR), 4(2), 219-224.

Sayidah, N., \& Assagaf, A. (2019). Tax amnesty from the perspective of tax official. Cogent Business and Management, 6(1). https://doi.org/10.108o/23311975.2019.1659909

Sista, N. P. A. (2019). Pengaruh Kesadaran Wajib Pajak, Kualitas Pelayanan Pajak, Kewajiban Moral, Dan Sanksi Pajak Terhadap Kepatuhan Wajib Pajak Kendaraan Bermotor Di Kantor Samsat Gianyar. Jurnal Sains, Akuntansi Dan Manajemen, 1(1), 142-179.

Tambun, S., \& Haryati, A. (2022). The Influence of Nationalism's Attitude and Tax Morals on Taxpayer Compliance through Tax Awareness. Journal of Accounting, Business and Finance Research, 14(1), 1. https://doi.org/10.20448/2002.141.1.7

Utami, E. (2018). Design Concept Integration Tax Payment System with Implementing Financial Technology. International Journal of Information Engineering and Electronic Business, 10(5), 15-22. https://doi.org/10.5815/ijieeb.2018.05.03

Whait, R. B., Christ, K. L., Ortas, E., \& Burritt, R. L. (2018). What do we know about tax aggressiveness and corporate social responsibility? An integrative review. Journal of Cleaner Production, 204, 542-552. https://doi.org/10.1016/j.jclepro.2018.08.334 